\title{
Impact of Credit Crunch on the Nigerian Economy
}

\author{
${ }^{1}$ Ezuwore C. N Obodoekwe, ${ }^{2}$ Alio Felix Chukwubuzo \\ ${ }^{1}$ Faculty of Business Administration, Department Of Accountancy, University Of Nigeria, Enugu Campus. \\ ${ }^{2}$ Faculty of Business Administration, Department Of Banking and Finance, University Of Nigeria, Enugu \\ Campus.
}

\begin{abstract}
This paper assesses the impact of credit crunch on the Nigerian economy. It discusses the meaning of credit crunch, the causes of credit crunch and its implications on the Nigerian economy.

Necessary measures taken to ameliorate the negative impacts of the credit crunch are discussed.

Keywords: Credit Crunch, Nigerian Economy

\section{Introdution}

In the years 2006-2008, only few of us were unaware of the financial crisis which was rocking the world, commonly known as the credit crunch.(Hunt,2009) Credit crunches are usually considered to be an extension of recessions. A credit crunch makes it nearly impossible for companies to borrow because lenders are scared of bankruptcies or defaults, which results in higher rates. The consequence is a prolonged recession (or slower recovery), which occurs as a result of the shrinking credit supply. It also occurs when there is a rapid reduction in the availability of loans from banks. This is when loans go sour, forcing the banks to tighten up lending standards. Credit crunch creates both positive and negative effects in the economy. By examining these effects carefully, we can gain a greater understanding of how credit crunch works and what we can learn from them. This situation has in turn had an adverse impact on the major stock markets of the world Credit crunch can create a situation in which banks are afraid togrant new loans. This fear causes many businesses and consumers to cut spending dramatically, or even close their doors, leading to a ripple effect on the economy as more businesses struggle to survive and consumers wealth erodes.
\end{abstract}

\section{What is credit Crunch?}

A credit crunch (also known as a credit squeeze or credit crisis) is a reduction in the general availability of lond (or credit) or a sudden tightening of the conditions required to obtain a loan from the banks.( .(http://en.wikipedia.org/wiki/loan.accessed on24/02/13) A credit crunch generally involves a reduction in the availability of credit independent of a rise in official interest rates. In such situations, the relationship between credit availability and interest rates has implicitly changed, such that either credit becomes less available at any given official interest rate, or there ceases to be a clear relationship between interest rates and credit availability (i.e. credit rationing occurs). Many times, a credit crunch is accompanied by a flight by lenders and investors, as they seek less risky investments (often at the expense of small to medium size enterprises). Securitization expanded credit but led to a decline in credit quality; this amplified the strain of declining housing prices and rising mortgage delinquencies that began in 2006.(http://en.wikipedia.org/wiki/flight_to_quality.accessed on24/02/13)

\section{Causes Of Credit Crunch In Nigeria}

The cause of the trouble is now pretty clear. Financial institutions, particularly investment banks, over extended their lending and investment activities beyond a normal level of prudence and this activity has spread to the high street commercial banks. The worst cases have been lending in the housing market beyond the level at which house buyers had the ability to repay their loans. This has created a large amount of bad debt which in turn has burst the bubble of rising house prices, and has vastly reduced the quality and stability of lending institutions assets. If that is all there is to it, the crunch would have been limited to those financial institutions making imprudent loans. Unfortunately, unsound mortgage assets have been parceled up and sold on to other financial institutions, and so the impact has been international spreading from the USA to Europe and to most other parts of the world particularly the financial centre's of Japan, Korea, China and Australia.

Additionally, many other types of financial assets suffered the same fate as mortgages and banks have gone on an investment spree well beyond what would have traditionally been regarded as prudent. The interlinking of financial institutions throughout the world has resulted in the spread of a lack of liquidity in financial institutions like a contagious disease. 
The malaise in the banks and other financial institutions led to a fall in house values and deprived viable businesses of the working capital which is necessary to keep them running effectively. These are the reasons why an economic slump is now forecast for the leading economies of the world. This in turn has led to substantial slide in stock markets throughout the world and therefore substantial fall in the value of public trading companies. Levels of employment are threatened as people lose their jobs due to retrenchment by companies unable to finance their normal business. In these ways, the credit crunch has spread from financial institutions to the 'real economy' of trading companies.

This potentially disastrous situation has created a serious challenge to individuals, governments and to the international community.

Other causes of Credit crunch are;

a) Inadequate Information

Inadequate Information is one of reason why banks might suddenly stop or reduce lending activity. For example, inadequate information about the financial condition of borrowers can lead to a boom in lending when financial institutions overestimate creditworthiness, while the sudden revelation of information suggesting that borrowers are or were less creditworthy can lead to a sudden contraction of credit. Other causes can include an anticipated decline in the value of the collateral used by the banks to secure the loans; an exogenous change in monetary conditions (for example, where the central bank suddenly and unexpectedly raises reserve requirements or imposes new regulatory constraints on lending); the central government imposing direct credit controls on the banking system; or even an increased perception of risk regarding the solvency of other banks within the banking system.(http://en Wikipedia.org/wiki/credit crunch. accessed on 13/03/13)

b) A sustained period of careless and inappropriate lending

A credit crunch is often caused by a sustained period of careless and inappropriate lending which results in losses for lending institutions and investors in debt when the loans turn sour and the full extent of bad debts becomes known. Careless lending tends to occur more often in fragmented, competitive credit markets in which lenders may compete with one another for market share and revenue by relaxing standards; by contrast, concentrated credit markets tend to have tighter standards and greater stability

.(http://en Wikipedia.org/wiki/credit crunch. accessed on 13/03/13)

c) Reduction in the market prices

Financial institutions facing losses may then reduce the availability of credit, and increase the cost of accessing credit by raising interest rates. In some cases, lenders may be unable to lend further, even if they wish, as a result of earlier losses.

The crunch is generally caused by a reduction in the market prices of previously "overinflated" assets and refers to the financial crisis that results from the price collapse. This can result in widespread foreclosure or bankruptcy for those investors and entrepreneurs who came in late to the market, as the prices of previously inflated assets generally drop precipitously. In contrast, a liquidity crisis is triggered when an otherwise sound business finds itself temporarily incapable of accessing the bridge finance it needs to expand its business or smooth its cash flow payments. In this case, accessing additional credit lines and "trading through" the crisis can allow the business to navigate its way through the problem and ensure its continued solvency and viability. It is often difficult to know, in the midst of a crisis, whether distressed businesses are experiencing a crisis of solvency or a temporary liquidity crisis.

In the case of a credit crunch, it may be preferable to "mark to market" - and if necessary, sell or go into liquidation if the capital of the business affected is insufficient to survive the post-boom phase of the credit cycle. In the case of a liquidity crisis on the other hand, it may be preferable to attempt to access additional lines of credit, as opportunities for growth may exist once the liquidity crisis is overcome.

A prolonged credit crunch is the opposite of cheap, easy and plentiful lending practices (sometimes referred to as "easy money", "loose credit", or "malinvestment"). During the upward phase in the credit cycle, asset prices may experience bouts of frenzied competitive, leveraged bidding, inducing inflation in a particular asset market. This can then cause a speculative price "bubble" to develop. As this upswing in new debt creation also increases the money supply and stimulates economic activity, this also tends to temporarily raise economic growth and employment.

Often it is only in retrospect that participants in an economic bubble realize that the point of collapse was obvious. In this respect, economic bubbles can have dynamic characteristics not unlike Ponzi schemes or Pyramid schemes. (http://en Wikipedia. Org /wiki/Economic_bubble-31/01/13)

As Keynes observed in 1931 during the Great Depresssion : "A sound banker, alas, is not one who foresees danger and avoids it, but one who, when he is ruined, is ruined in a conventional way along with his fellows, so that no one can really blame him.( http://en.wikipedia.org/wiki/John Maynard_ KeynesCredit_crunch accessed-31/01/13) 


\section{The Impact Of The Present Financial Crisis, Would Be Felt In Nigeria In The Following Areas:}

\section{- International Trade}

Nigeria's economy is crude oil export oriented. Our major trading in America, Europe and Asia has been the hardest hit by the crisis. If the economy of these countries continues to face a crunch, the risk of reduced commodity expert for Nigeria is increased. This would in turn greatly impact on the reserve from oil with the falling oil prices. Reduction in good reserve would ultimately affect the provision of goods and basic amenities in the budget of the coming year. For the first time in Nigeria's history, the 2009 budget presented to the National Assembly was in deficit.

\section{- Foreign Investment And Foreign Aid}

Certain States of Nigeria are presently relying on funds off shore financiers to fund mega projects such as road construction and power generation. With this crisis, it is probable that the completion of some of these projects could be prolonged. Similarly, Nigeria relies on several foreign grants and funding from developed countries to complement public spending on education, health care delivery, transportation, amongst others. The crisis may cause a squeeze on grants to Nigeria as some of the countries we rely on for funding are the worst hit by the crisis. Similarly, grants from donor agencies such as the IMF, World Bank and USAID could also be affected as they in turn rely heavily on the contributions of the G7 States, which would reduce as the credit crunch persists.

\section{- Banking Sector}

Although the Nigeria banking industry enjoys a low exposure to world financial markets, many banks with off-shore credit lines have begun to experience reduction or outright cancellation of credit lines as many of the foreign banks are suffering from the crisis already.. This has resulted in the weakening of the banks credit portfolio. A good number of Nigerian banks are involved in joint venture financing with foreign banks for mega projects in oil, Aviation and Communication sectors. These projects would be threatened by the crisis.

\section{- Foreign Reserves}

The country-s Foreign Reserve is denominated principally in dollars. The value of the dollars is the therefore a key factor to Nigeria-s well being. For example' a weaker dollar may cause a shrink in our external reserve. Nigerians have also raised concerns about the safety of our Foreign Reserves, kept in off-shore; Some banks managing these Reserves are already being affects by the crisis such as credit Suisse and ABN Amro. However, the Central Bank Governor has given assurance on the safety of the Reserves.

\section{- Stock Prices}

Prices in stocks the world over have crashed in the past few weeks. The Nigeria stock market is not immune as share prices have fallen heavily over the past 5 months. Though share prices seem to be stabilizing gradually, it has been predicted that the global cash crunch is likely to further amplify the price slump on the Nigeria stock market.

\section{Measures Taken To Solve These Problems}

In the wake of the global financial crisis, the Central Bank of Nigeria (CBN) has taken some of the following measure to forestall the spill over the crisis into the Nigeria economy.

\section{- Liquidity:}

In order to lubricate the system, $\mathrm{CBN}$ has taken proactive steps to infuse more liquidity into financial market. In September 2006, CBN reduced the Monetary Policy Rate from $10.25 \%$ to $9.27 \%$, cut down the liquidity ratio from 40 percent to 30 percent and then released another N1.2reillion into the economy by reducing the cash reserve requirement from 4 percent to 2 percent. These measures are aimed at strengthening the country's financial system against the brewing if Nigeria financial crisis.

\section{- Foreign Reserve}

The fundamentals of the Nigerian economy are strong this is evidenced by the fact that as of October 01, 2008, the quantum of Nigeria foreign reserve stood at about \$63billion, while the Foreign Direct Investments (FDI) remained strong at $\$ 8.5$ billion. These statistics proved that Nigeria's vulnerability to the credit induced crisis through currency depreciation is reduced. 


\section{- Banking System}

The banking consolidation exercise undertaken in the banking sector in 2006 has proved to be a buffer against this crisis. As it has resulted in stronger Nigerian banks which are better able to withstand the financial crisis. In addition, a few months ago CBN suspended the common according to year-end policy for banks and also re-scheduled existing banks facilities granted for the purpose of buying shares into longer term tenure thereby reducing crisis.

\section{- Fiscal Measures}

The Federal Government has also put in place mechanisms aimed at insulating the economy from the crisis.

i Under the 2009 Budget, the bench mark for crude oils was drastically reduced from an earlier proposed $\$ 62.5$ to 45 prices per barrel. This was done to reflect the global economic realities.

ii Encouragement of inter-bank lending within the financial sector.

iii The Monetary Policy Committee (CPC) has also directed that CBN could henceforth buy and sell securities through two-way quotes to further stabilize the Nigeria foreign exchange market.

\section{Conclusion}

What is absolutely clear is that financial markets have become globalised in the same way as product markets. Additionally, governmental supervision and control over the behaviour of financial institutions are bound to increase. Thus the traditional free markets in money and credit dealing will be much more limited than in the past, thus modifying one of the traditional bases of capitalist organization.

In Nigeria, despite the wide spread belief that Nigeria would not be initially affected by the crisis, it is important to emphasize that the global economy is inter-related. Thus, what affects the global economy would eventually affect our nation. It is only a matter of time.

\section{References}

[1] Barth, James R., Gerard Caprio, and Daniel E. Nolle,( 2004). "Comparative International Characteristics of Banking," Washington: Comptroller of the Currency, Economic and Policy Analysis Working Paper 2004-1 (January).

[2] Black, Fischer, Merton Miller, and Richard Posner, (1978.) “An Approach to the Regulation of Bank Holding Companies," Journal of Business, 5 (July), pp. 379- 412.

[3] Brock, Philip L.,( 1999.) "Financial Safety Nets: Lessons from Chile.” Seattle: University of Washington, (March),

[4] Calomiris, Charles W.,( 1999.) "Building an Incentive-Compatible Safety Net," Journal of Banking and Finance, 23(October), pp. 1499-1519.

[5] Carnell, Richard,( 1993.) "The Culture of Ad Hoc Discretion," in George Kaufman and Robert Litan (ed.), Assessing Bank Reform: FDICIA One Year Later, Washington: Brookings Institution, pp. 113-121.

[6] Cukierman, Alex, Stephen Webb, and Bilin Neyapti, (1992.) "Measuring the Independence of Central Banks and its Effect on Policy Outcomes," World Bank Economic Review, 6 (No. 3), pp. 353-398.

[7] Demirgüç-Kunt, Aslı, and Enrica Detragiache, (1998.) "The Determinants of Banking Crises: Evidence from Developing and Developed Countries," IMF Staff Papers, 45 (no. 1), pp. 81-109.

[8] Investigation," Journal of Monetary Economics, 49, pp. 1373-1406.

[9] Demirgüç-Kunt, Asle, and Edward J. Kane, (2002.) Journal of Economic Perspectives, 16 (No. 2), pp. $175-195$

[10] Demirgüç-Kunt, Aslı, and Tolga Tobact,(2000.) "Deposit Insurance Around the World:

[11] A Data Base," World Bank manuscript.

[12] Diamond, Douglas,( 1984.) "Financial Intermediation and Delegated Monitoring," Review of Economic Studies, 51(July), pp. 343414.

[13] Diamond, Douglas, and Philip Dybvig,( 1983.) "Bank Runs, Deposit Insurance, and Liquidity,” Journal of Political Economy, 91(June), pp. 401-19.

[14] Garcia, Gillian G.H.(, 1999.) "Deposit Insurance: A Survey of Actual and Best Practices," Washington: International Monetary Fund, Working Paper No. 99/54.

[15] George Cooper,(2008) The Origin of Financial Crises London, Harriman House) ISBN 1-905641-85-0

[16] Graham Turner,(2008) The Credit Crunch: Housing Bubbles, Globalization and the Worldwide Economic Crisis (2008: London, Pluto Press), ISBN 978-0-7453-2810-2

[17] Michael Simkovic,(2009) "Secret Liens and the Financial Crisis of 2008", American Bankruptcy Law Journal.

[18] Goldstein, Morris, and Philip Turner, (1996.) Banking Crises in Emerging Economies: Origins and Policy Options. Basle: Bank for International Settlements.

[19] Hovakimian, Armen, Edward Kane, and Luc Laeven, (2003.) "How Country and Safety-Net Characteristics Affect Bank's RiskShifting," Journal of Financial Services Research, 23 (No. 2) pp. 177-204.

[20] Hunt H G(2009) Thegsm News, The Newsletter of Greenwich School of Management. London.

[21] Jensen, Michael C., and William Meckling, (1976. )"Theory of the Firm: Managerial Behavior, Agency Costs, and Ownership Structure," Journal of Financial Economics, 3(June), pp. 305-360.

[22] Kane, Edward J.,( 2000.) “Designing Financial Safety Nets to Fit Country Circumstances.” (unpublished). 